\title{
Role of favipiravir in the treatment of adult patients with moderate to severe COVID2 19: a single-center, prospective, observational, sequential cohort study from Hungary
}

\section{Balint Gergely SZABO ( $\sim$ szabo.balint.gergely@gmail.com )}

South Pest Central Hospital, National Institute of Hematology and Infectious Diseases, Saint Ladislaus Campus; Semmelweis University, School of PhD Studies

\section{Katalin Szidonia LENART}

South Pest Central Hospital, National Institute of Hematology and Infectious Diseases, Saint Ladislaus Campus

\section{Borisz PETRIK}

Semmelweis University, Faculty of Medicine

\section{Zsofia GASPAR}

Semmelweis University, Faculty of Medicine

\section{Zsofia BALOGH}

South Pest Central Hospital, National Institute of Hematology and Infectious Diseases, Saint Ladislaus Campus

\section{Zsuzsanna BANYAI}

South Pest Central Hospital, National Institute of Hematology and Infectious Diseases, Saint Ladislaus Campus

\section{Emese BANYASZ}

South Pest Central Hospital, National Institute of Hematology and Infectious Diseases, Saint Ladislaus Campus

\section{Jozsef BUDAl}

South Pest Central Hospital, National Institute of Hematology and Infectious Diseases, Saint Ladislaus Campus

\section{Eszter CZEL}

South Pest Central Hospital, National Institute of Hematology and Infectious Diseases, Saint Ladislaus Campus

\section{Katalin FRIED}

South Pest Central Hospital, National Institute of Hematology and Infectious Diseases, Saint Ladislaus Campus

\section{Adrienn HANUSKA}


South Pest Central Hospital, National Institute of Hematology and Infectious Diseases, Saint Ladislaus Campus

\section{Noemi KISS-DALA}

South Pest Central Hospital, National Institute of Hematology and Infectious Diseases, Saint Ladislaus Campus

\section{Csaba LORINCZI}

South Pest Central Hospital, National Institute of Hematology and Infectious Diseases, Saint Ladislaus Campus

\section{Krisztina NEMESI}

South Pest Central Hospital, National Institute of Hematology and Infectious Diseases, Saint Ladislaus Campus

\section{Janos KADAR}

South Pest Central Hospital, National Institute of Hematology and Infectious Diseases, Saint Ladislaus Campus

\section{Eva Livia NAGY}

South Pest Central Hospital, National Institute of Hematology and Infectious Diseases, Saint Ladislaus Campus

\section{Akos OSVALD}

South Pest Central Hospital, National Institute of Hematology and Infectious Diseases, Saint Ladislaus Campus

\section{Edina PETROVICZ}

South Pest Central Hospital, National Institute of Hematology and Infectious Diseases, Saint Ladislaus Campus

\section{Alexandra RICZU}

South Pest Central Hospital, National Institute of Hematology and Infectious Diseases, Saint Ladislaus Campus

\section{Judit SZANKA}

South Pest Central Hospital, National Institute of Hematology and Infectious Diseases, Saint Ladislaus Campus

\section{Beata SZATHMARY}

South Pest Central Hospital, National Institute of Hematology and Infectious Diseases, Saint Ladislaus Campus

\section{Andrea SZOMBATI}

South Pest Central Hospital, National Institute of Hematology and Infectious Diseases, Saint Ladislaus Campus

\section{Szilvia TOTH}

South Pest Central Hospital, National Institute of Hematology and Infectious Diseases, Saint Ladislaus Campus

\section{Zsuzsanna VARNAl}


South Pest Central Hospital, National Institute of Hematology and Infectious Diseases, Saint Ladislaus Campus

\section{Orsolya WOLLER}

South Pest Central Hospital, National Institute of Hematology and Infectious Diseases, Saint Ladislaus Campus

\section{Janos SZLAVIK}

South Pest Central Hospital, National Institute of Hematology and Infectious Diseases, Saint Ladislaus Campus

\section{Botond LAKATOS}

South Pest Central Hospital, National Institute of Hematology and Infectious Diseases, Saint Ladislaus Campus

\section{Research Article}

Keywords: COVID-19, favipiravir, antiviral, cohort study

Posted Date: December 7th, 2020

DOl: https://doi.org/10.21203/rs.3.rs-122353/v1

License: (c) (i) This work is licensed under a Creative Commons Attribution 4.0 International License. Read Full License 
Role of favipiravir in the treatment of adult patients with moderate to severe COVID19: a single-center, prospective, observational, sequential cohort study from Hungary Balint Gergely SZABO ${ }^{1,2, *}$, Katalin Szidonia LENART ${ }^{1, *}$, Borisz PETRIK ${ }^{3}$, Zsofia GASPAR $^{3}$, Zsofia BALOGH ${ }^{1}$, Zsuzsanna BANYAI $^{1}$, Emese BANYASZ $^{1}$, Jozsef BUDAI ${ }^{1}$, Eszter CZEL ${ }^{1}$, Katalin FRIED ${ }^{1}$, Adrienn HANUSKA ${ }^{1}$, Noemi KISS-DALA ${ }^{1}$, Csaba LORINCZI $^{1}$, Krisztina NEMESI ${ }^{1}$, Janos KADAR ${ }^{1}$, Eva Livia NAGY ${ }^{1}$, Akos OSVALD ${ }^{1}$, Edina PETROVICZ ${ }^{1}$, Alexandra RICZU ${ }^{1}$, Judit SZANKA ${ }^{1}$, Beata SZATHMARY ${ }^{1}$, Andrea SZOMBATI $^{1}$, Szilvia TOTH ${ }^{1}$, Zsuzsanna VARNAI ${ }^{1}$, Orsolya WOLLER ${ }^{1}$, Janos SZLAVIK ${ }^{1}$, Botond LAKATOS ${ }^{1}$

${ }^{1}$ South Pest Central Hospital, National Institute of Hematology and Infectious Diseases, Saint Ladislaus Campus (H-1097 Albert Florian ut 5-7., Budapest, Hungary)

${ }^{2}$ Semmelweis University, School of PhD Studies (H-1085 Ulloi ut 26., Budapest, Hungary)

${ }^{3}$ Semmelweis University, Faculty of Medicine (H-1085 Ulloi ut 26., Budapest, Hungary)

* The authors contributed equally to the manuscript (in equo loco).

\section{ORIGINAL RESEARCH ARTICLE}

Corresponding author: Balint Gergely SZABO; szabo.balint.gergely@gmail.com; +3630/644-5976.

Postal address: H-1097 Albert Florian ut 5-7., Budapest, Hungary.

Keywords: COVID-19, favipiravir, antiviral, cohort study

Running title: Favipiravir treatment of adult COVID-19 patients

Abstract word count: 250

Abstract character count: 1807

Article word count: 2500

Article character count: 19700

Number of tables: 3

Number of references: 19 
ABBREVIATIONS

29 ARDS - acute respiratory distress syndrome

30 BAL - bronchoalveolar lavage

31 COVID-19 - coronavirus disease-19

32

$\mathrm{CRP}-\mathrm{C}$-reactive protein

33

CS - cytokine storm

34

CT - computed tomography

35

ECDC - European Centre for Disease Prevention and Control

EUCAST - European Committee on Antimicrobial Susceptibility Testing

37 FVP - favipiravir

38

ICU - intensive care unit

$\mathrm{IQR}$ - interquartile region

40

LDH - lactate dehydrogenase

41

LOS - length of stay

42 PCR - polymerase chain reaction

43 RCT - randomized clinical trials

44 SARS-CoV-2 - severe acute respiratory syndrome coronavirus-2

45 SOC - standard of care

46 STROBE - Strengthening the Reporting of Observational studies in Epidemiology 


\section{ABSTRACT}

Background: Preliminary data suggests that favipiravir might have a role in COVID-19 treatment. Our aim was to assess the role of favipiravir in the treatment of COVID-19.

Methods: A single-center, prospective, observational, sequential cohort study was performed among consecutive adults hospitalized with PCR-confirmed COVID-19 between MarchJuly,2020. Patients were screened for inclusion by a priori criteria, and were included in the favipiravir cohort if SOC+FVP, or the non-favipiravir group if SOC \pm other antiviral medications without FVP were administered for $>48$ hours. Treatment allocation was done per national guidelines. For COVID-19 diagnosis and severity, ECDC and WHO definitions were utilized, and daily per protocol hospital follow-up was done. Primary composite endpoint was disease progression (14-day all-cause death, need for mechanical ventilation, or immunomodulatory therapy). For statistical comparison, Fisher's exact test and MannWhitney U-test were used.

Results: In all, 75 patients were included per cohort. In the FVP cohort, chronic heart disease $(36 / 75,48.0 \%$ vs. $16 / 75,21.3 \%, \mathrm{p}<0.01)$ and diabetes mellitus $(23 / 75,30.7 \%$ vs. 10/75, $13.3 \%, \mathrm{p}<0.01)$ were more prevalent, hospital LOS $(18.5 \pm 15.5$ days vs. $13.0 \pm 8.5$ days, $\mathrm{p}<0.01)$ was higher. Disease progression $(17 / 75,22.7 \%$ vs. $10 / 75,13.3 \%, \mathrm{p}=0.13), 14$-day allcause death $(9 / 75,12.0 \%$ vs. $10 / 75,13.3 \%, p=0.8)$ and need for mechanical ventillation $(8 / 75$, $10.7 \%$ vs. $4 / 75,5.3 \%, p=0.22$ ) were similar between groups. Immunomodulatory therapies were administered frequently among patients receiving FVP (10/75, 13.3\% vs. 1/75, 1.3\%, $\mathrm{p}<0.01)$.

Conclusions: In this study, favipiravir did not seem to affect disease progression. Further data are needed to position this drug among the anti-SARS-CoV-2 armamentarium. 


\section{INTRODUCTION}

As the pandemic caused by severe acute respiratory syndrome coronavirus-2 (SARSCoV-2) is ongoing, investigators are searching for therapeutic strategies to cure coronavirus disease-19 (COVID-19). As of September 2020, the number antiviral drugs proven to effectively inhibit viral replication is low [1]. Furthermore, it is not known which antivirals are unequivocally able to attenuate the pathological progression of COVID-19 in most patients with different severity. Favipiravir (FVP) is an antiviral pyrazinecarboxamide derivative, licensed for influenza in Japan. Data from the literature suggested that favipiravir might also be useful in COVID-19 treatment $[2,3]$. Therefore, our goal was to assess the effect of favipiravir in the treatment of adult patients hospitalized at our centre with moderate to severe COVID-19.

\section{METHODS}

\subsection{Study design and settings}

A single-center, prospective, observational, sequential cohort study was performed among adults diagnosed and hospitalized with COVID-19 at our centre between March 15 July 15, 2020 (first COVID-19 case was confirmed on March 4 in Hungary). Our centre is a national-level referreal institution, and the main COVID-19 centers of the country with $>150$ dedicated beds. The study was in accordance with the Helsinki Declaration, as well as national ethical standards. The institutional review board approved the study protocol, and informed consent was obtained from every patient.

\subsection{Patient eligibility and inclusion}

Consecutive adult ( $\geq 18$ years of age) patients hospitalized at our centre during the study period with respiratory SARS-CoV-2 polymerase chain reaction (PCR) confirmed COVID-19 cases, irrespective of COVID-19 disease severity, were eligible for inclusion. To overcome selectional bias, all patients were prospectively screened for inclusion by our COVID-19 team (composed of attending physicians), by daily real-time visits at the ward and intensive care unit (ICU), and case assessment using hospital electronic records. Selection was done by using a priori inclusion/exclusion criteria. Inclusion criteria were: 1) PCR based confirmation of COVID-19 diagnosis in a clinically compatible case, with any disease severity; 2) received standard of care (SOC) or any of the exposure treatments for $>48$ hours after diagnosis. Exclusion criteria were: 1) the patient was intubated, died or discharged within $\leq 48$ hours after diagnosis; 2) received SOC or any of the exposure treatments for $\leq 48$ 
hours after diagnosis; 3) received any antiviral medication before diagnosis 4) patient data was not accessible through hospital electronic database.

Included patients were grouped into two sequential cohorts in 1:1 fashion, according to treatment exposures: favipiravir (FVP) cohort consisted of patients receiving SOC+FVP, non-favipiravir (non-FVP) cohort included patients who were administered SOC \pm other antiviral medications. Other possible antiviral medications were chloroquine, hydroxychloroquine, lopinavir/ritonavir, remdesivir and oseltamivir (please refer to the adequate section for details).

\subsection{Data collection}

A dedicated database was established for the study aim by manual extraction of data from hospital electronic records and written charts. Data was transferred anonymously to an $a$ priori standardized case report form. Data collected: 1) age and gender; 2) comorbidities; 3) intensive care unit (ICU) admission during hospitalization; 4) length of stay (LOS) and ICU LOS; 4) clinical parameters at COVID-19 diagnosis (symptom onset, COVID-19 severity, supplementary oxygen demand, peripheral oxygen saturation, acute respiratory distress syndrome [ARDS], cytokine storm [CS], acute respiratory failure); 5) laboratory parameters at diagnosis (blood leucocyte, absolute neutrophil granulocyte, lymphocyte and platelet counts, hemoglobin, CRP, procalcitonin, serum ferritin, high sensitivity cardiac Troponin-I, serum interleukin-6, serum creatinine, LDH and D-dimer); 6) microbiological and radiological parameters at diagnosis (blood cultures and chest computed tomography [CT]); 7) characteristics of antimicrobial therapies and supportive care; 8) characteristics of immunomodulatory therapies; 9) study outcomes. Variables with $\geq 5 \%$ of missing measurements were omitted from final analysis, no imputation was seeked.

\subsection{Diagnostic and therapeutic strategies at our centre during the pandemic}

At our centre, we follow the European Centre for Disease Prevention and Control (ECDC) COVID-19 case definition for diagnosis ascertainment [4]. A clinically suspicious case presentation (cardinal symptoms: fever, dyspnea, cough) is confirmed if a respiratory specimen is positive for SARS-CoV-2 nucleic acid by PCR. Respiratory specimens are taken by a team of trained nurses with oro-/nasopharyngeal sampling in spontaneously breathing patients, or by mini-BAL in ventilated patients. Disease severity is determined by World Health Organization (WHO) criteria [5]. Disease onset is the first day of symptom apperance as reported by the patient, or day of first PCR positivity if symptom appearance could not be 
reported. The day of first SARS-CoV-2 PCR positivity is given as COVID-19 diagnosis day. Acute respiratory failure and ARDS were defined following the 2012 Berlin criteria, CS is diagnosed by trends of clinical and laboratory parameters and HScore, as proposed by Mehta et al. $[6,7]$.

At our centre, COVID-19 patient care is facilitated by standardized in-house diagnostic and therapeutic strategies, composed of written protocols and check-lists updated since March 2020 according to literature evidence. Physical examination, laboratory studies, arterial blood gas analyses are done daily. Imaging studies (chest X-ray and/or chest CT) are done on the day of COVID-19 diagnosis, and days $+7,+14$, and if disease progression (persistent fevers for $\geq 72$ hours, deteriorating hypoxaemia) or clinical instability (newly onset dyspnea, chest pain, hypotension, altered mentation) is documented. Every febrile (tympanal temperature $\geq 37.8^{\circ} \mathrm{C}$ ) patient has 2 sets of blood cultures taken. Testing for SARS-CoV-2 PCR negativity is initiated 24 hours after defervescence and clinical stability. Respiratory samples for SARS-CoV-2 PCR are collected every 48 hours, PCR negativity is documented on the day when two consecutive samples are proven to be negative. Daily follow-up of patients is done until death or hospital discharge, post-discharge follow-up is not routinely arranged. Microbiological diagnostics are performed at the Microbiology Laboratory of our centre.

COVID-19 antiviral therapies are allocated per protocol, in an open-label and nonrandomized fashion (excluding patients in randomized clinical trials), but allocation is affected by drug availability on a national level. At our centre, treatment allocation is done in accordance with the "Hungarian Coronavirus Handbook" [8]. Before favipiravir introduction to Hungary (May 15, 2020), all patients received other antiviral medications: chloroquine (1g loading dose, $1 \times 500 \mathrm{mg}$ maintenance thereafter, minimum of 7 days) or hydroxychloroquine (2x400mg loading dose, 2x200mg maintenance thereafter, min. of 5 days) or lopinavir/ritonavir (200/50mg in 2x2 capsules, min. of 7 days), depending on patient contraindications and drug availability. As the influenza season was overlapping with the first month of the epidemic in Hungary, oseltamivir $(2 \times 75 \mathrm{mg})$ was also administered to patients, pending influenza A/B respiratory PCR results. Remdesivir was not available in Hungary during the study period. After favipiravir distribution, all patients received it per protocol in monotherapy at our centre $(2 \times 1600 \mathrm{mg}$ loading dose, $2 \times 600 \mathrm{mg}$ maintenance thereafter, min. of 10 days). Patients are routinely receiving SOC (on-demand oxygen therapy, respiratory support, intravenous fluid replenishment, antipyretics, antitussive and bronchodilator drugs). 
Empirical antibiotics per Infectious Diseases Society of America (IDSA) community-acquired pneumonia guideline are administered if disease progression or clinical instability is documented, immunomodulatory agents are administered in a clinical study to patients with CS or critical COVID-19, per COVID-19 team initiation [9].

\subsection{Outcomes}

The primary endpoint was disease progression, a negative composite of any of the following: 1) 14-day all-cause death, 2) need for mechanical ventilation, 3) need for immunomodulatory therapy for COVID-19 at ward or ICU. 14-day all-cause death was defined as exitus within 14 days from COVID-19 diagnosis during hospital stay. Need for mechanical ventilation was defined as a completed endotracheal intubation in relation to COVID-19, per decision of an ICU crash team. Need for immunomodulatory therapy was defined if any immunomodulatory drug was initiated at any dose, suggested by the "Hungarian Coronavirus Handbook" (at our centre, depending on availability: tocilizumab, ruxolitinib, baricitinib, intravenous immunoglobulin, reconvalescent plasma or systemic corticosteroids), excluding systemic corticosteroids started for alternative causes.

Secondary endpoints were 14-day all-cause mortality, need for mechanical ventilation, need for immunomodulatory therapy, rate of PCR negativity (at the end of hospitalization or sooner). Time analyses were done between cohorts by comparing time intervals from diagnosis day to disease progression, to all-cause mortality, to mechanical ventilation, to immunomodulatory therapy, to PCR negativity.

\subsection{Statistical analysis}

Continuous variables are expressed as mediantinterquartile range (IQR). Normality was checked with the Shapiro-Wilks-test. Categorical variables are expressed as absolute numbers (n) with relative percentages (\%). Statistical comparisons were done with MannWhitney U-test or Fisher's exact test. For identification of independent risk factors associating with disease progression, uni- and multivariate binomial logistic regression was performed. All plausible parameters and those with a $p$-value of $\leq 0.1$ in univariate analysis were entered into a forward stepwise multivariate logistic regression (entry criterion: $p=0.05$, removal criterion: $p=0.1$ ). Maximal number of predictors was estimated with the common 1:10 rule-ofthumb, goodness-of-fit was tested by the Hosmer-Lemeshow test. For all tests, a two-tailed $p$ value of $<0.05$ determined statistical significance. Data collection was completed with Microsoft Office Excel 2016, tests were calculated using IBM SPSS Statistics 23. For 
reporting, we adhere to the Strengthening the Reporting of Observational studies in Epidemiology (STROBE) Statement [10].

\section{RESULTS}

\subsection{Baseline and clinical characteristics}

In all, 150 patients were enrolled during the study period, 75 in both cohorts. Baseline and clinical characteristics are described in Table 1. Median age was 66.0 \pm 12.4 years, with representation of older patients in the FVP group (71.5 \pm 15.1 vs. $61.0 \pm 21.5$ years, $\mathrm{p}<0.01)$. Genders and most comorbidities were equally distributed between cohorts, essential hypertension $(57 / 75,76.0 \%$ vs. 38/75, 50.7\%, p<0.01) chronic heart disease $(36 / 75,48.0 \%$ vs. 16/75, 21.3\%, p<0.01), diabetes mellitus $(18 / 75,24.0 \%$ vs. $6 / 75,8.0 \%, \mathrm{p}=0.01)$ and chronic cerebral disease $(23 / 75,30.7 \%$ vs. $10 / 75,13.3 \%$, $\mathrm{p}<0.01)$ were more prevalent in the FVP cohort. At diagnosis, 35/75 (53.3\%) and 41/75 (54.7\%) patients had severe disease in the FVP and non-FVP cohorts, respectively $(\mathrm{p}=0.41)$, and ARDS or CS was not documented. Need for oxygen supportation was needed in similar rates $(27 / 75,36.0 \%$ vs. $21 / 75,28.5 \%$, p=0.29). Documented bloodstream-infections were rare $(1 / 75,0.7 \%)$. Patients in the FVP group had higher white blood cell $\left(6.5 \pm 4.2 \times 10^{9} / \mathrm{L}\right.$ vs. $\left.5.5 \pm 3.3 \times 10^{9} / \mathrm{L}, \mathrm{p}=0.04\right)$, platelet counts $\left(225 \pm 117 \times 10^{9} / \mathrm{L}\right.$ vs. $\left.191 \pm 108 \times 10^{9} / \mathrm{L}, \mathrm{p}=0.03\right)$, serum creatinine $(86.0 \pm 49.3 \mu \mathrm{mol} / \mathrm{L}$ vs. $71.0 \pm 37.5 \mu \mathrm{mol} / \mathrm{L}, \mathrm{p}=0.03)$ and D-dimer $(1163 \pm 2038 \mathrm{ng} / \mathrm{mL}$ vs. $850 \pm 479 \mathrm{ng} / \mathrm{mL}, \mathrm{p}=0.03)$, lower hemoglobin levels $(117 \pm 24 \mathrm{~g} / \mathrm{l}$ vs. $131 \pm 20 \mathrm{~g} / \mathrm{L}, \mathrm{p}<0.01)$. The rate of chest CT positivity did not differ between cohorts $(54 / 64,84.4 \%$ vs. $13 / 14,92.8 \%, \mathrm{p}=0.67)$.

\subsection{Outcomes, therapeutic approaches}

Outcomes and therapeutic approaches are detailed in Table 2. Disease progression showed no statistically significant difference $(17 / 75,22.7 \%$ vs. $10 / 75,13.3 \%, \mathrm{p}=0.13)$ between cohorts. Rates of 14-day all-cause mortality $(9 / 75,12.0 \%$ vs. 10/75, 13.3\%, p=0.8) and need for mechanical ventilation $(8 / 75,10.7 \%$ vs. $4 / 75,5.3 \%, p=0.22)$ were also similar, need for immunomodulatory therapies was higher among patients receiving FVP (10/75, $13.3 \%$ vs. $1 / 75,1.3 \%, \mathrm{p}<0.01)$. FVP expuosure was not retained as an independent covariate in multivarite logistic regression modelling disease progression (Table 3.). Although there was a statistically non-significant tendency for higher PCR negativity rate (55/75, 73.0\% vs. $43 / 75,57.3 \%, \mathrm{p}=0.05)$, median time to PCR negativity was significantly longer $(22.0 \pm 15.5$ days vs. $13.0 \pm 12.0$ days, $\mathrm{p}<0.01$ ) in the FVP cohort. Median time from diagnosis to disease 
progression $(8.0 \pm 9.0$ days vs. $4.5 \pm 9.8, \mathrm{p}=0.08)$ and time to exitus (16.0 \pm 14.0 days vs. $8.5 \pm 10.3$ days, $\mathrm{p}=0.03$ ) were both longer among patients receiving FVP.

Although supportive therapies were needed in equivalent rates $(43 / 75,57.3 \%$ vs. 46/75, 61.3\%, p=0.73), hospital LOS (18.5 \pm 16.0 vs. $13.0 \pm 9.0$ days, <0.01) was higher with similar ICU admissions $(12 / 75,16.0 \%$ vs. 5/75, 6.7\%, p=007). In the non-FVP cohort, patients mostly received chloroquin or hydroxychloroquin $(5 / 75,6.7 \%$ vs. $61 / 75,81.3 \%$, $\mathrm{p}<0.01)$. Preferred antibiotics were azithromycin $(19 / 75,25.3 \%$ vs. $44 / 75,58.7 \%, \mathrm{p}<0.01)$ and ceftriaxon $(13 / 75,17.3 \%$ vs. $28 / 75,37.3 \%, \mathrm{p}<0.01)$. Tocilizumab was given frequently to patients with cytokine storm $(9 / 75,12.0 \%$ vs. $1 / 75,1.3 \%, \mathrm{p}=0.01)$.

\section{DISCUSSION}

\subsection{Present study}

We performed a single-center, prospective observational, sequential cohort study by enrolling 150 hospitalized adult patients with moderate to severe COVID-19, receiving either favipiravir or other antiviral medications with standard of care during the first 4 months of SARS-CoV-2 pandemic in Hungary. There was no statistically significant differences in time to antiviral therapy initiation from PCR positivity, COVID-19 disease severity, need for oxygen supportation and ICU admittance rates between cohorts. Disease progression, 14-day all-cause mortality, need for invasive mechanical ventilation and PCR negativity rate seemed to be unaffected by favipiravir exposure compared to other antivirals, and there was higher demand for immunomodulatory therapy administration among patients in the favipiravir cohort.

\subsection{Previous studies}

Pharmacological approaches, as well as clinical studies describing favipiravir treatment strategies for COVID-19 patients were reported in the literature. Although favipiravir demonstrated good in vitro inhibitory activity against SARS-CoV-2, the optimal pharmacological dose for COVID-19 treatment has yet to be determined, as the dose recommendations (as used in our study) based on pharmacokinetic experiments and clinical trials. Data of studies involving patients with other severe viral infections (influenzavirus, Ebolavirus) might be insufficient to maintain an adequate serum concentration, especially in critically ill patients $[2,11,12]$. Although a review found that favipiravir has a favourable safety profile concerning serious adverse events, the main side effects are hyperuricaemia, 
teratogenicity and QTc prolongation. Establishment of long-term safety profile among COVID-19 patients needs more pharmacovigilance data [13].

According to data from the literature, clinical usefulness of favipiravir in COVID-19 may somewhat be limited. A prospective clinical trial randomizing 240 adult patients in an 1:1 fashion with clinically confirmed COVID-19 to conventional therapy and umifenovir or favipiravir reported that although favipiravir administration associated with shorter time to defervescence and diminishment of cough, the drug could not significantly improve 7-day clinical recovery rate as a primary endpoint. Furthermore, rates of noninvasive mechanical ventilation, supplementary oxygen demand or all-cause mortality did not show differences between groups [14]. An open-labeled non-randomized study conducted by matching 35 microbiologically confirmed COVID-19 patients treated with favipiravir and 45 patients receiving lopinavir/ritonavir (all with additional interferon-alpha inhalation), within one week after onset of symptomps. Authors documented statistically higher improvement rates in chest imaging and faster viral clearance among patients receiving favipiravir, but effect of favipiravir on disease progression or mortality rates were not reported [15]. A recently published multicenter phase II/III randomized trial enrolled patients with moderate COVID19 within a median of 6.7 days from start of symptomps. The primary efficacy endpoint was the elimination of SARS-CoV-2 by Day 10 . On day 5, viral clearance was significantly more prevalant in the favipiravir arm $(\mathrm{p}=0.018)$, but on day 10 the difference was statistically nonsignificant $(\mathrm{p}=0.155)$. Authors conclude that in their pilot study, favipiravir appeared beneficious among moderately ill patients [16]. In small case series studies, favipiravir was administered with nafamostat mesylate or methylprednisolone for COVID-19 patients in different disease stages, but due to the lack of control groups and antiviral combination usage, the extent favipiravir effect on clinical cure remains ambiguous [17-19]. In all, we think that our findings could be reflected by data from current literature, and the role for favipiravir should not be overestimated in the treatment of adults with moderate to severe COVID-19.

\subsection{Limitations}

Our study had several limitations. As the pandemic is still ongoing, knowledge about COVID-19 is changing fast, and despite best efforts, per protocol treatment allocation might have been lagging behind literature evidence. National drug availability might have biased treatment allocation. The initiation of alternative antiviral medications might have been biased by (contra)indication. Age and comorbidity differences between our cohorts could represent the temporal progression of the epidemic in Hungary: younger people were affected sooner in 
294 larger numbers, and this might have confounded some baseline characteristics due to the 295 sequential cohort design. The number of included patients is relatively low, however, an exact 296 a priori study size calculation was not feasible due to study design and enrollment. Chest CT 297 was not readily obtainable from some patients due to technical reasons.

\section{CONCLUSION}

Among adult patients hospitalized with COVID-19, an overall beneficial effect of 300 favipiravir on disease progression could not be proven in this study. Due to limitations, 301 further prospective trial data are needed to elucidate the role of favipiravir in COVID-19 302 treatment. 


\begin{tabular}{|c|c|c|c|c|}
\hline PARAMETER & $\begin{array}{c}\text { Total } \\
(\mathbf{n}=\mathbf{1 5 0})\end{array}$ & $\begin{array}{c}\begin{array}{c}\text { FVP cohort } \\
(n=75)\end{array} \\
\end{array}$ & $\begin{array}{c}\begin{array}{c}\text { Non-FVP cohort } \\
(n=75)\end{array} \\
\end{array}$ & $p$ value \\
\hline Age (years, median $\pm \mathrm{IQR}, \min -\max$ ) & $66.0 \pm 12.4(20.0-93.0)$ & $71.5 \pm 15.1(24.0-93.0)$ & $61.0 \pm 21.5(20.0-91.0)$ & $<0.01$ \\
\hline Male gender $(\mathrm{n}, \%)$ & $76(50.7)$ & $37(49.3)$ & $39(52.0)$ & 0.74 \\
\hline ICU admission during hospitalization (n, \%) & $17(11.3)$ & $12(16.0)$ & $5(6.7)$ & 0.07 \\
\hline $\begin{array}{l}\text { Time from disease onset to antiviral therapy } \\
\text { (days, median } \pm \mathrm{IQR}, \text { min-max) }\end{array}$ & $3.0 \pm 6.0(1-34)$ & $2.0 \pm 3.0(1-34)$ & $7.5 \pm 9.0(1-21)$ & $<0.01$ \\
\hline $\begin{array}{l}\text { Time from positive PCR to antiviral therapy }{ }^{\mathrm{a}} \\
\text { (days, median } \pm \mathrm{IQR}, \min -\max \text { ) }\end{array}$ & $1.0 \pm 2.0(1-31)$ & $1.0 \pm 2.0(1-31)$ & $1.0 \pm 2.0(1-6)$ & 0.88 \\
\hline $\begin{array}{l}\text { Comorbidities (n, \%): } \\
\text { - Essential hypertension } \\
\text { - Chronic heart disease } \\
\text { - Chronic vascular disease } \\
\text { - Chronic pulmonary disease } \\
\text { - Chronic renal disease } \\
\text { - Chronic hepatic disease } \\
\text { - Chronic cerebral disease } \\
\text { - Diabetes mellitus } \\
\text { - Active oncological malignancy } \\
\text { - Active hematolgical malignancy } \\
\text { - Systemic autoimmune disease } \\
\text { - Chronic systemic corticosteroid treatment } \\
\text { - Chronic systemic immunosuppressive treatment } \\
\text { - Smoking }\end{array}$ & $\begin{array}{c}95(63.3) \\
52(34.7) \\
14(9.3) \\
20(13.3) \\
9(6.0) \\
5(3.3) \\
24(16.0) \\
33(22.0) \\
21(14.0) \\
13(8.7) \\
7(4.7) \\
2(1.3) \\
2(1.3) \\
2(1.3)\end{array}$ & $\begin{array}{c}57(76.0) \\
36(48.0) \\
10(13.3) \\
11(14.7) \\
7(9.3) \\
4(5.3) \\
18(24.0) \\
23(30.7) \\
15(20.0) \\
9(12.0) \\
2(2.7) \\
2(2.7) \\
0 \\
2(2.7)\end{array}$ & $\begin{array}{c}38(50.7) \\
16(21.3) \\
4(5.3) \\
9(12.0) \\
2(2.7) \\
1(1.3) \\
6(8.0) \\
10(13.3) \\
6(8.0) \\
4(5.3) \\
5(6.7) \\
0 \\
2(2.7) \\
0\end{array}$ & $\begin{array}{c}<\mathbf{0 . 0 1} \\
<\mathbf{0 . 0 1} \\
0.1 \\
0.6 \\
0.09 \\
0.18 \\
\mathbf{0 . 0 1} \\
<\mathbf{0 . 0 1} \\
0.05 \\
0.16 \\
0.16 \\
0.14 \\
0.23 \\
0.16\end{array}$ \\
\hline $\begin{array}{l}\text { Clinical characteristics at COVID-19 diagnosis: } \\
\text { - Peripheral oxygen saturation }(\%, \text { median } \pm \text { IQR, min-max) } \\
\text { - Need for oxygen supportation (n, \%) } \\
\text { - ARDS }(\mathrm{n}, \%) \\
\text { - Acute respiratory failure }(\mathrm{n}, \%) \\
\text { - CS }(\mathrm{n}, \%)\end{array}$ & $\begin{array}{c}95 \pm 7(51-99) \\
48(32.0) \\
0 \\
1(0.7) \\
0 \\
\end{array}$ & $\begin{array}{c}94 \pm 7(51-99) \\
27(36.0) \\
0 \\
0 \\
0 \\
\end{array}$ & $\begin{array}{c}95 \pm 7(78-99) \\
21(28.0) \\
0 \\
1(1.3) \\
0 \\
\end{array}$ & $\begin{array}{l}0.94 \\
0.29 \\
\text { n.a. } \\
\text { n.a. } \\
\text { n.a. }\end{array}$ \\
\hline $\begin{array}{l}\text { Severity of COVID- } 19^{\mathrm{b}}(\mathrm{n}, \%) \\
\text { - Non-severe disease } \\
\text { - Severe disease }\end{array}$ & $\begin{array}{l}74(49.3) \\
76(50.7) \\
\end{array}$ & $\begin{array}{l}40(53.3) \\
35(46.7) \\
\end{array}$ & $\begin{array}{l}34(45.3) \\
41(54.7) \\
\end{array}$ & 0.41 \\
\hline $\begin{array}{l}\text { Laboratory characteristics at COVID-19 diagnosis } \\
(\text { median } \pm \mathrm{IQR}, \min -\max ): \\
\text { - White blood cell count }\left(\times 10^{9} / \mathrm{L}\right) \\
\text { - Neutrophil granulocyte count }\left(\times 10^{9} / \mathrm{L}\right) \\
\text { - Lymphocyte count }\left(\times 10^{91} /\right) \\
\text { - Platelet count }\left(\times 10^{9} / \mathrm{L}\right) \\
\text { - Hemoglobin level }(\mathrm{g} / \mathrm{L}) \\
\text { - C-reactive protein }(\mathrm{mg} / \mathrm{L}) \\
\text { - Procalcitonin }(\mu \mathrm{g} / \mathrm{L}) \\
\text { - Interleukin- } 6(\mathrm{pg} / \mathrm{mL}) \\
\text { - Serum ferritin }(\mu \mathrm{g} / \mathrm{L}) \\
\text { - Cardiac Troponin-I }(\mathrm{ng} / \mathrm{mL}) \\
\text { - Serum cratinine }(\mu \mathrm{mol} / \mathrm{L}) \\
\text { - Serum LDH }(\mathrm{IU} / \mathrm{L}) \\
\text { - Serum D-dimer }(\mathrm{ng} / \mathrm{mL})\end{array}$ & $\begin{array}{c}6.2 \pm 3.7(2.3-21.7) \\
4.0 \pm 2.9(0.4-20.1) \\
1.2 \pm 0.7(0.3-3.7) \\
203 \pm 93(12-743) \\
124 \pm 32(67-163) \\
41 \pm 94(1-316) \\
0.0 \pm 0.1(0-92.8) \\
16.1 \pm 20.0(2.7-76.9) \\
397 \pm 520(37-6001) \\
0.012 \pm 0.026(0.001-2.171) \\
75.0 \pm 35.5(36.0-470.0) \\
512 \pm 242(214-2240) \\
1111 \pm 1405(160-49937) \\
\end{array}$ & $\begin{array}{c}6.5 \pm 4.2(2.7-21.7) \\
4.2 \pm 2.9(0.4-20.1) \\
1.2 \pm 0.8(0.3-3.7) \\
225 \pm 117(12-743) \\
117 \pm 24(67-152) \\
37 \pm 90(1-229) \\
0.1 \pm 0.1(0-92.8) \\
13.9 \pm 22.3(2.7 \pm 76.9) \\
403 \pm 555(37-6001) \\
0.012 \pm 0.025(0.001-2.171) \\
86.0 \pm 49.3(36.0-446.0) \\
491 \pm 232(214-2240) \\
1163 \pm 2038(160-49937) \\
\end{array}$ & $\begin{array}{c}5.5 \pm 3.3(2.3-16.4) \\
3.8 \pm 3.6(1.6-14.9) \\
1.1 \pm 0.7(0.3-2.6) \\
191 \pm 108(78-414) \\
131 \pm 20(89-163) \\
44.7 \pm 91.9(1-316) \\
0.0 \pm 0.1(0-14.4) \\
20.0 \pm 10.6(15.6-46.0) \\
364 \pm 219(84-1268) \\
0.008 \pm 0.02(0.002-0.056) \\
71.0 \pm 37.5(37.0-470.0) \\
534 \pm 275(241-1370) \\
850 \pm 479(316-1319) \\
\end{array}$ & $\begin{array}{c}\mathbf{0 . 0 4} \\
0.09 \\
0.07 \\
\mathbf{0 . 0 3} \\
<\mathbf{0 . 0 1} \\
0.52 \\
0.08 \\
1.0 \\
0.72 \\
0.37 \\
\mathbf{0 . 0 3} \\
0.51 \\
\mathbf{0 . 0 3} \\
\end{array}$ \\
\hline $\begin{array}{l}\text { Blood cultures taken per patient }(\mathrm{n}, \%) \\
\text { Detected bloodstream-infections (n, \%) }\end{array}$ & $\begin{array}{c}76(50.7) \\
1(0.7)\end{array}$ & $\begin{array}{c}36(48.0) \\
1(1.3)\end{array}$ & $\begin{array}{c}40(53.3) \\
0\end{array}$ & $\begin{array}{l}0.46 \\
0.31\end{array}$ \\
\hline Chest CT positive for COVID-19 / chest CT obtained & $67 / 78(85.9)$ & $54 / 64(84.4)$ & $13 / 14(92.8)$ & 0.67 \\
\hline
\end{tabular}

positive for COVID-19/ ches

$67 / 78$ (85.9)

54 / 64 (84.4)

${ }^{a}$ From first positive SARS-CoV-2 PCR, sampled from the respiratory tract

${ }^{\mathbf{b}}$ Per World Health Organization criteria

306 n.a. Not applicable.

Table 1. Baseline and clinical characteristics of adult COVID-19 patients included in the study, 


\begin{tabular}{|c|c|c|c|c|}
\hline PARAMETER & $\begin{array}{c}\text { Total } \\
(\mathbf{n}=\mathbf{1 5 0})\end{array}$ & $\begin{array}{c}\text { FVP cohort } \\
(n=75)\end{array}$ & $\begin{array}{c}\begin{array}{c}\text { Non-FVP cohort } \\
(n=75)\end{array} \\
\end{array}$ & $p$ value \\
\hline Disease progression $(\mathrm{n}, \%)$ & $27(18.0)$ & $17(22.7)$ & $10(13.3)$ & 0.13 \\
\hline 14-day all-cause mortality (n, \%) & $19(12.7)$ & $9(12.0)$ & $10(13.3)$ & 0.8 \\
\hline Need for invasive mechanical ventilation (n, \%) & $12(8.0)$ & $8(10.7)$ & $4(5.3)$ & 0.22 \\
\hline Need for immunomodulatory therapy $(\mathrm{n}, \%)$ & $13(8.7)$ & $10(13.3)$ & $1(1.3)$ & $<0.01$ \\
\hline Rate of PCR negativity $(\mathrm{n}, \%)$ & $99(66.0)$ & $55(73.0)$ & $43(57.3)$ & 0.05 \\
\hline $\begin{array}{l}\text { Time from diagnosis to disease progression } \\
\text { (days, median } \pm \text { IQR, min-max) }\end{array}$ & $7.0 \pm 7.0(1.0-14.0)$ & $8.0 \pm 9.0(3.0-14.0)$ & $4.5 \pm 9.8(1.0-12.0)$ & 0.08 \\
\hline $\begin{array}{l}\text { Time from diagnosis to exitus } \\
\text { (days, median } \pm \text { IQR, } \min -\max \text { ) }\end{array}$ & $12.0 \pm 7.5(1.0-50.0)$ & $16.0 \pm 14.0(6.0-50.0)$ & $8.5 \pm 10.3(2.0-14.0)$ & $\mathbf{0 . 0 3}$ \\
\hline $\begin{array}{l}\text { Time from diagnosis to mechanical ventilation } \\
\text { (days, median } \pm \text { IQR, min-max) }\end{array}$ & $4.5 \pm 5.3(1.0-12.0)$ & $5.5 \pm 5.3(3.0-12.0)$ & $4.5 \pm 3.5(1.0-12.0)$ & 0.79 \\
\hline $\begin{array}{l}\text { Time from diagnosis to immunomodulatory therapy } \\
\text { (days, median } \pm \mathrm{IQR}, \min -\max \text { ) }\end{array}$ & $7.0 \pm 5.5(3.0-14.0)$ & $7.0 \pm 6.0(3.0-14.0)$ & $4.0 \pm 0(4.0-4.0)$ & 1.0 \\
\hline $\begin{array}{l}\text { Time from positive PCR to PCR negativity } \\
\text { (days, median } \pm \text { IQR, } \min -\max \text { ) }\end{array}$ & $18.5 \pm 10.5(3.0-55.0)$ & $22.0 \pm 15.5(3.0-55.0)$ & $13.0 \pm 12.0(3.0-32.0)$ & $<0.01$ \\
\hline LOS (days, median \pm IQR, min-max) & $15.0 \pm 10.8(2.0-49.0)$ & $18.5 \pm 15.5(3.0-49.0)$ & $13.0 \pm 8.5(2.0-46.0)$ & $<0.01$ \\
\hline ICU LOS (days, median \pm IQR, min-max) & $5.0 \pm 2.0(1.0-25.0)$ & $5.0 \pm 2.0(2.0-12.0)$ & $5.0 \pm 5.0(1.0-25.0)$ & 0.79 \\
\hline $\begin{array}{l}\text { Supportive therapies needed }{ }^{\mathrm{a}}(\mathrm{n}, \%) \\
\text { - Nasal cannula } \\
\text { - Venturi mask } \\
\text { - Non-invasive ventilation } \\
\text { - Vasopressor therapy } \\
\text { - Renal replacement therapy } \\
\text { - Parenteral nutrition } \\
\text { - Prone positioning } \\
\text { - Any }\end{array}$ & $\begin{array}{c}79(52.7) \\
41(27.3) \\
4(2.7) \\
11(7.3) \\
1(0.7) \\
1(0.7) \\
3(2.0) \\
89(59.3)\end{array}$ & $\begin{array}{c}38(50.7) \\
18(24.0) \\
4(5.3) \\
8(10.7) \\
1(1.3) \\
1(1.3) \\
0 \\
43(57.3)\end{array}$ & $\begin{array}{c}41(54.7) \\
23(30.7) \\
0 \\
3(4.0) \\
0 \\
0 \\
3(4.0) \\
46(61.3)\end{array}$ & $\begin{array}{l}0.62 \\
0.35 \\
0.12 \\
0.11 \\
0.31 \\
0.31 \\
0.24 \\
0.73\end{array}$ \\
\hline $\begin{array}{l}\text { Antiviral therapies given }(\mathrm{n}, \%) \text { : } \\
\text { - Favipiravir } \\
\text { - Chloroquin/hydroxychloroquin } \\
\text { - Oseltamivir } \\
\text { - Lopinavir/ritonavir } \\
\text { - Remdesivir } \\
\text { - Any }\end{array}$ & $\begin{array}{c}75(50.0) \\
66(44.0) \\
34(22.7) \\
7(4.7) \\
0 \\
139(92.7) \\
\end{array}$ & $\begin{array}{c}75(100.0) \\
5(6.7) \\
0 \\
0 \\
0 \\
75(100.0) \\
\end{array}$ & $\begin{array}{c}0 \\
61(81.3) \\
34(45.3) \\
7(9.3) \\
0 \\
64(85.3) \\
\end{array}$ & $\begin{array}{c}<0.01 \\
<0.01 \\
<0.01 \\
0.01 \\
\text { n.a. } \\
<0.01 \\
\end{array}$ \\
\hline $\begin{array}{l}\text { Antibacterial therapies given }(\mathrm{n}, \%) \\
\text { - Ampicillin } \\
\text { - Amoxicillin/clavulanate } \\
\text { - Cefazolin } \\
\text { - Ceftriaxon } \\
\text { - Cefepim } \\
\text { - Piperacillin/tazobactam } \\
\text { - Meropenem } \\
\text { - Imipenem/cilastatin } \\
\text { - Vancomycin } \\
\text { - Linezolid } \\
\text { - Azithromycin } \\
\text { - Clarithromycin } \\
\text { - Levofloxacin } \\
\text { - Doxycyclin } \\
\text { - Gentamicin } \\
\text { - Any }\end{array}$ & $\begin{array}{c}1(0.7) \\
5(3.3) \\
3(2.0) \\
41(27.3) \\
2(1.3) \\
20(13.3) \\
9(6.0) \\
15(10.0) \\
3(2.0) \\
2(1.3) \\
63(42.0) \\
1(0.7) \\
13(8.7) \\
10(6.7) \\
4.0(2.7) \\
108(72.0)\end{array}$ & $\begin{array}{c}1(1.3) \\
1(1.3) \\
3(4.0) \\
13(17.3) \\
1(1.3) \\
13(17.3) \\
7(9.3) \\
12(16.0) \\
3(4.0) \\
2(2.7) \\
19(25.3) \\
1(1.3) \\
1(1.3) \\
0 \\
4(5.3) \\
47(62.7)\end{array}$ & $\begin{array}{c}0 \\
4(5.3) \\
0 \\
28(37.3) \\
1(1.3) \\
7(9.3) \\
2(2.7) \\
3(4.0) \\
0 \\
0 \\
44(58.7) \\
0 \\
12(16.0) \\
10(13.3) \\
0 \\
61(81.3)\end{array}$ & $\begin{array}{c}0.31 \\
0.17 \\
0.24 \\
<\mathbf{0 . 0 1} \\
\text { n.a. } \\
0.14 \\
0.85 \\
0.01 \\
0.08 \\
0.15 \\
<\mathbf{0 . 0 1} \\
0.31 \\
<\mathbf{0 . 0 1} \\
<\mathbf{0 . 0 1} \\
\mathbf{0 . 0 4} \\
\mathbf{0 . 0 1}\end{array}$ \\
\hline $\begin{array}{l}\text { Immunomodulatory therapies given }(\mathrm{n}, \%) \text { : } \\
\text { - Tocilizumab } \\
\text { - Ruxolitinib } \\
\text { - Baricitinib } \\
\text { - Intravenous immunoglobulin } \\
\text { - Reconvalescent plasma } \\
\text { - Systemic corticosteroid }\end{array}$ & $\begin{array}{c}10(6.7) \\
0 \\
0 \\
2(1.3) \\
0 \\
3(2.0)\end{array}$ & $\begin{array}{c}9(12.0) \\
0 \\
0 \\
2(2.7) \\
0 \\
3(4.0)\end{array}$ & $\begin{array}{c}1(1.3) \\
0 \\
0 \\
0 \\
0 \\
0\end{array}$ & $\begin{array}{c}\mathbf{0 . 0 1} \\
\text { n.a. } \\
\text { n.a. } \\
0.49 \\
\text { n.a. } \\
0.24\end{array}$ \\
\hline
\end{tabular}

$311{ }^{a}$ Excluding invasive mechanical ventilation.

$312{ }^{\mathbf{b}}$ Alone or in combination.

313 n.a. Not applicable.

Table 2. Outcomes and therapeutic approaches to adult COVID-19 patients included in the study, 


\begin{tabular}{|c|c|c|c|c|c|c|}
\hline & \multirow{2}{*}{$\begin{array}{c}\text { Disease progression } \\
(\mathrm{n}=27)\end{array}$} & \multirow{2}{*}{$\begin{array}{l}\text { No disease progression } \\
(\mathrm{n}=123)\end{array}$} & \multicolumn{2}{|c|}{ Univariate analysis } & \multicolumn{2}{|c|}{ Multivariate analysis } \\
\hline & & & $\mathrm{OR}(95 \% \mathrm{CI})$ & $p$ value & $\mathrm{OR}(95 \% \mathrm{CI})$ & $p$ value \\
\hline Age & $74.0 \pm 23.1(41.0-91.0)$ & $66.0 \pm 12.9(20.0-93.0)$ & $1.04(1.01-10.9)$ & 0.01 & - & \\
\hline Male gender & $12(44.0)$ & $64(52.0)$ & $0.74(0.32-1.72)$ & 0.47 & & \\
\hline Time from disease onset to antiviral therapy & $3.3 \pm 7.8(1-34)$ & $3.5 \pm 7.8(1-34)$ & $0.91(0.81-1.01)$ & $0.07 *$ & n.a. & \\
\hline Essential hypertension & $19(70.4)$ & $76(61.8)$ & $1.64(0.64-4.17)$ & 0.3 & & \\
\hline Chronic heart disease & $18(66.7)$ & $34(27.6)$ & $\begin{array}{c}5.81(2.32- \\
14.70) \\
\end{array}$ & $<0.01$ & $4.27(1.41-12.98)$ & 0.01 \\
\hline Chronic cerebral disease & $5(18.5)$ & $19(15.4)$ & $1.29(0.43-3.84)$ & 0.64 & & \\
\hline Diabetes mellitus & $10(37.0)$ & $23(18.7)$ & $2.69(1.08-6.71)$ & 0.03 & - & \\
\hline Need for oxygen supportation & $16(59.3)$ & $32(26.0)$ & $4.13(1.74-9.80)$ & 0.01 & - & \\
\hline Severe COVID-19 & $26(96.3)$ & $50(27.0)$ & $\begin{array}{c}38.5(5.0- \\
333.30) \\
\end{array}$ & $<0.01$ & $21.28(2.32-200.0)$ & $<0.01$ \\
\hline Any supportive therapy needed & $26(96.3)$ & $63(51.2)$ & $\begin{array}{c}5.10(1.82- \\
14.30) \\
\end{array}$ & $<0.01$ & - & \\
\hline Any antibacterial therapy needed & $22(81.5)$ & $86(69.9)$ & $1.89(0.67-5.37)$ & 0.23 & & \\
\hline Any antiviral therapy needed & $25(92.6)$ & $114(92.7)$ & $1.01(0.21-4.98)$ & 0.98 & & \\
\hline Treatment with favipiravir & $17(63.0)$ & $58(47.2)$ & $1.91(0.81-4.48)$ & 0.14 & - & \\
\hline
\end{tabular}

*The parameter was not included in the final model as co-linearity was not proven by the Box-Tidwell test with Bonferroni's post hoc correction $(p<0.01)$

Table 3. Independent predictors of disease progression among adult COVID-19 patients included in the study, grouped by progression occurence 
323 Conflict of interest: The authors declare no conflicts of interest regarding this article. The 324 ICMJE Form for Disclosure of Potential Conflicts of Interest was completed by the corresponding author on behalf of all co-authors.

Funding: The article itself did not receive any external funding. BGSz received the EFOP3.6.3-VEKOP-16-2017-00009 Doctorate Grant, and was supported by the ÚNKP-19-3-I-SE74 New National Excellence Program of the Ministry of Innovation and Technology of Hungary. The funding sources had no involvement in the preparation, writing, interpretation, or submission of this article.

Acknowledgements: The authors would like to thank the healthcare workers of our centre for their sacrifice during these times. Together, we are stronger. Preliminary results of the study were presented at ECCVID 2020 (September 23-25, 2020).

Access to data: Anonymised data of patients are available from the corresponding author on reasonable request.

Authors' contributions: BGSZ and LKSZ contributed equally to the manuscript (in equo loco). BGSZ: management of patients, data collection, data analysis, preparation of study protocol, preparation of the manuscript; LKSZ: management of patients, data collection, data analysis, preparation of study protocol, preparation of the manuscript; BP: data collection, data analysis; ZSG: data collection, data analysis; ZSB: management of patients, review of the manuscript; ZSB: management of patients, review of the manuscript; EB: management of patients, review of the manuscript; JB: management of patients, review of the manuscript; EC: management of patients, review of the manuscript; KF: management of patients, review of the manuscript; AH: management of patients, review of the manuscript; NKD: management of patients, review of the manuscript; CSL: management of patients, review of the manuscript; $\mathrm{KN}$ : management of patients, review of the manuscript; JK: management of patients, review of the manuscript; ELN: management of patients, review of the manuscript; AO: management of patients, review of the manuscript; EP: management of patients, review of the manuscript; AR: management of patients, review of the manuscript; JSZ: management of patients, review of the manuscript; BSZ: management of patients, review of the manuscript; ASZ: management of patients, review of the manuscript; SZT: management of patients, review of the manuscript; ZSV: management of patients, review of the manuscript; OW: management of patients, review of the manuscript; JSZ: management of patients, review of the manuscript, 
354 COVID-19 Team Leader; BL: management of patients, preparation of study protocol, 355 preparation and review of the manuscript.

356 Ethics approval: The Institutional Review Board of South Pest Central Hospital, National 357 Institute of Hematology and Infectious Diseases (Budapest, Hungary) approved the study 358 protocol. Approval for the use of off-label investigational drugs was granted by our 359 institutional review board, as well as the National Institute of Pharmacy and Nutrition in 360 relation to the COVID-19 surge in Hungary 361 (ogyei.gov.hu/tajekoztato_a_veszelyhelyzet_megszunesevel_kapcsolatos_a_covid_19_jarvany 362 _idejen_kulonos_meltanylast_erdemlo_betegellatasi_erdekhez_kotheto_gyogyszeralkalmazas 363 ok_bejelenteserol). 
365 [1] National Institutes of Health. COVID-19 Treatment Guidelines. 2020. https://www.covid19treatmentguidelines.nih.gov/whats-new/. (Accessed 2020.09.01).

367 [2] Shannon A, Selisko B, Le N, Huchting J, Touret F, Piorkowski G, et al. Favipiravir strikes the SARS-CoV-2 at its Achilles heel, the RNA polymerase. bioRxiv 2020.

[3] Coomes EA, Haghbayan H. Favipiravir, an antiviral for COVID-19? J Antimicrob 370 Chemother 2020;75:2013-4.

371 [4] European Centre for Disease Prevention and Control. Case definition for coronavirus disease 2019 (COVID-19), as of 29 May 2020. 2020. https://www.ecdc.europa.eu/en/covid19/surveillance/case-definition. (Accessed 2020.09.01).

[5] World Health Organization. Clinical management of COVID-19. 2020. 2020.09.01.).

[6] Force ADT, Ranieri VM, Rubenfeld GD, Thompson BT, Ferguson ND, Caldwell E, et al. Acute respiratory distress syndrome: the Berlin Definition. JAMA 2012;307:2526-33.

[7] Mehta P, McAuley DF, Brown M, Sanchez E, Tattersall RS, Manson JJ. COVID-19: consider cytokine storm syndromes and immunosuppression. Lancet 2020;395:1033-4. [8] Emberi Erőforrások Minisztériuma. A 2020. évben azonosított új koronavírus (SARSCoV-2) okozta fertőzések (COVID-19) megelőzésének és terápiájának kézikönyve. 2020. https://koronavirus.gov.hu/sites/default/files/sites/default/files/imce/magyar_koronavirus_kezi konyv_2020.06.25.pdf. (Accessed 2020.09.01.) [In Hungarian].

[9] Metlay JP, Waterer GW, Long AC, Anzueto A, Brozek J, Crothers K, et al. Diagnosis and Treatment of Adults with Community-acquired Pneumonia. An Official Clinical Practice Guideline of the American Thoracic Society and Infectious Diseases Society of America. Am J Respir Crit Care Med 2019;200:e45-e67.

[10] von Elm E, Altman DG, Egger M, Pocock SJ, Gøtzsche PC, Vandenbroucke JP. The Strengthening the Reporting of Observational Studies in Epidemiology (STROBE) statement: guidelines for reporting observational studies. Lancet 2007;370:1453-7.

392 [11] Irie K, Nakagawa A, Fujita H, Tamura R, Eto M, Ikesue H, et al. Pharmacokinetics of 393 Favipiravir in Critically Ill Patients With COVID-19. Clin Transl Sci 2020;13:880-5.

394 [12] Du YX, Chen XP. Favipiravir: Pharmacokinetics and Concerns About Clinical Trials for 2019-nCoV Infection. Clin Pharmacol Ther 2020;108:242-7. 
396 [13] Pilkington V, Pepperrell T, Hill A. A review of the safety of favipiravir - a potential 397 treatment in the COVID-19 pandemic? J Virus Erad 2020;6:45-51.

398 [14] Chen C, Zhang Y, Huang J, Yin P, Cheng Z, Wu J, et al. Favipiravir versus Arbidol for 399 COVID-19: A Randomized Clinical Trial. medRxiv 2020.

400 [15] Cai Q, Yang M, Liu D, Chen J, Shu D, Xia J, et al. Experimental Treatment with 401 Favipiravir for COVID-19: An Open-Label Control Study. Engineering (Beijing) 2020.

402 [16] Ivashchenko AA, Dmitriev KA, Vostokova NV, Azarova VN, Blinow AA, Egorova AN, 403 et al. AVIFAVIR for Treatment of Patients with Moderate COVID-19: Interim Results of a 404 Phase II/III Multicenter Randomized Clinical Trial. Clin Infect Dis 2020.

405 [17] Murohashi K, Hagiwara E, Kitayama T, Yamaya T, Higa K, Sato Y, et al. Outcome of 406 early-stage combination treatment with favipiravir and methylprednisolone for severe 407 COVID-19 pneumonia: A report of 11 cases. Respir Investig 2020.

408 [18] Doi K, Ikeda M, Hayase N, Moriya K, Morimura N, Group C-US. Nafamostat mesylate 409 treatment in combination with favipiravir for patients critically ill with Covid-19: a case 410 series. Crit Care 2020;24:392.

411 [19] Yamamura H, Matsuura H, Nakagawa J, Fukuoka H, Domi H, Chujoh S. Effect of 412 favipiravir and an anti-inflammatory strategy for COVID-19. Crit Care 2020;24:413. 